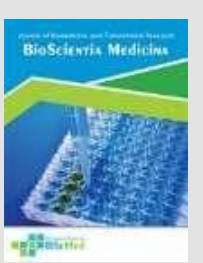

Bioscientia Medicina: Journal of Biomedicine \&

Translational Research

Journal Homepage: www.bioscmed.com

\title{
Efficacy of Aloe Vera Hydrogel in Inhibition the Growth of Campylobacter rectus and Provetella intermedia Bacteria
}

\section{Chandra Susanto ${ }^{*}$, Member Reni Purba ${ }^{1}$, Ridha Mahrani $^{1}$, Ramayani Efendi ${ }^{1}$}

${ }^{1}$ Department of Periododontics, University Prima Indonesia. Medan. Indonesia

\author{
A R T I C L E I N F O \\ Keywords: \\ Antibacterial \\ Campylobacter Rectus and provetella \\ intermedia \\ Aloe Vera \\ Hydrogel \\ *Corresponding author: \\ Chandra Susanto \\ E-mail address: \\ drgchandrasusantospperio@gmail.com
}

All authors have reviewed and approved the final version of the manuscript.

\section{https://doi.org/10.32539/bsm.v5i8.344}

\begin{abstract}
A B S T R A C T
Background: Campylobacter rectus and Provetella intermedia bacteria as the main etiology causes of periodontal disease. One of the locally synthesized antimicrobials that is widely used for the treatment of periodontitis is Chlorhexidine, however this drug has side effects when used continuously. To overcome this, an alternative periodontitis therapy with medicinal plants is needed. This study aims to determine the effectiveness of hydrogel Aloe vera antibacterial concentrations of $2.5 \%, 5 \%, 10 \%$ and $20 \%$ in the bacteria Campylobacter rectus and Provetella intermedia. Methods: This study was a laboratory experimental study with posttest only control group design in vitro. The samples were Campylobacter rectus and Provetella intermedia. The number of groups in this study was six. The sample size was determined by Federer's formula and obtained four replications for each group. Data collection by measuring the inhibition diameter using a slide caliper. Data were analyzed using oneway ANOVA and posthoc LSD. Results: The results showed that there was a difference in the diameter of the hydrogel Aloe vera inhibition with a concentration of $2.5 \%, 5 \%$, $10 \%, 20 \%$ and a positive control for Campylobacter rectus and Provete1la intermedia bacteria. Conclusion: This study concluded that there is an antibacterial effectiveness of hydrogel Aloe vera in concentrations of $2.5 \%, 5 \%, 10 \%$ and $20 \%$ on Campylobacter rectus and Provetella intermedia bacteria.
\end{abstract}

\section{Introduction}

Periodontal disease is a common oral health problem after caries [1,2]. According to the 2017 Global Burden of Disease Study, this disease is the 11th most common disease, affecting nearly 20\% - 50\% of the global population and will increase as humans grow older [3,4]. Chronic periodontitis most commonly occurs in adults over 30 years of age, characterized by complex and progressive chronic inflammation (5-9). Campylobacter rectus and Provetella intermedia are two bacterial pathogens which are the main etiologies of periodontal disease [10-14].

The basis of periodontal treatment is eliminating bacterial growth with antibacterials [7]. Antibacterial drugs are administered in various dosage forms, including hydrogel [15-17]. This preparation is suitable for administration of antibacterial drugs because of its high hydrophilicity, unique three-dimensional tissue and cell adhesion [18]. Currently, hydrogels with antibacterial function are the main focus of biomedical research [19].

A locally synthesized antimicrobial that is widely used in treating periodontitis is Chlorhexidine [20]. From the research results of Binshabaib et al (2020), chlorhexidine $0.2 \%$ effectively decreased the growth of P. gingivalis bacteria [21-22]. However, daily use of chlorhexidine has side effects [23]. To overcome this, 
alternative therapy with medicinal plants is needed [24].

Aloe vera is a medicinal plant that comes from the Liliaceae family. Since ancient times, Aloe vera has been used as anti-inflammatory, antimicrobial, and immune boosting [25]. Based on the results of research by Gharibi et al (2015), aloe vera extract has antibacterial activity against S.aureus, MRSA, P. aeruginosa and K. pneumoniae bacteria [26]. Aloe vera contains several bioactive components that have antibacterial properties, namely anthraquinones [25]. The most anthraquinone content is found in the latex or exudate layer which is brownish yellow between the skin and the meat of aloe vera [27]).

Many sophisticated antibacterial hydrogels have been developed, but researchers still have not found studies on the effectiveness of the $20 \%$ concentration of aloe vera hydrogel antibacterial against Campylobacter rectus and Provetella intermedia bacteria. From the above thought, the researcher was interested in conducting research on "The Antibacterial Effectiveness of Hydrogel Aloe Vera on Campylobacter rectus and Provetella intermedia Bacteria".

\section{Method}

This type of research is an experimental laboratory with posttest only control group design. The research sample is the bacteria Campylobacter rectus and Provetella intermedia. This study consisted of 5 groups, namely hydrogel aloe vera 2.5\%, 5\%, 10\%, 20\%, and negative control (hydrogel). The study sample size was determined according to Federer's formula and obtained replications of 5 times for each group. Aloe vera used in this study was taken purposively and has been identified in USU's Herbarium Medenesse. The process of making aloe vera extract by maceration method uses $70 \%$ ethanol. In this study, the main basic ingredient for the manufacture of hydrogel preparations is na-alginate mixed with other supporting ingredients to obtain $10 \mathrm{ml}$ of aloe vera hydrogel for each concentration. Then, the hydrogel aloe vera antibacterial activity test was performed against Campylobacter rectus and Provetella intermedia by diffusion. The clear zone formed around the media in order to measure its diameter using a sliding caliper. The collected data were then analyzed by using the oneway ANOVA and posthoc LSD statistical tests.

\section{Results}

Based on the results of the study, the mean diameter of hydrogel aloe vera inhibition was $2.5 \%, 5 \%$, $10 \%$ and $20 \%$ in Campylobacter rectus bacteria were $8.21 \pm 0.35 \mathrm{~mm}, 10.97 \pm 0.26 \mathrm{~mm}, 13.00 \pm 0.25 \mathrm{~mm}$, and $16.35 \pm 0.42 \mathrm{~mm}$, whereas there were no obstacles in the negative control.

Based on the results of the study, the mean diameter of hydrogel aloe vera inhibition concentration of $2.5 \%, 5 \%, 10 \%$ and $20 \%$ in Provetella intermedia bacteria was $8.54 \pm 0.18 \mathrm{~mm}, 10.48 \pm 0.43 \mathrm{~mm}, 12.17$. $\pm 0.65 \mathrm{~mm}$, and $16.87 \pm 0.42 \mathrm{~mm}$, whereas there were no obstacles in the negative control.

Before testing the effectiveness of hydrogel aloe vera antibacterial on Campylobacter rectus and Provetella intermedia bacteria, first all data were carried out for normality with the Shapiro Wilik statistical test.

Based on the results of the normality test, the value of $\mathrm{p}>0.05$ was obtained, which means that all data were normally distributed. Furthermore, data analysis with oneway Anova and posthoc LSD. to determine the antibacterial effectiveness of hydrogel aloe vera 2,5\%, $5 \%, 10 \%$ and $20 \%$ in the bacteria Campylobacter rectus and Provetella intermedia.

Based on the results of the oneway Anova statistical test on Campylobacter rectus and Provetella intermedia bacteria, each obtained $\mathrm{p}$ value $=0.00$, which means that there is a significant difference in inhibition diameter between hydrogel Aloe vera 2.5\%, 5\%, 10\%, and $20 \%$. From these results it can be stated that there is an antibacterial effectiveness of hydrogel Aloe vera $2.5 \%, 5 \%, 10 \%$ and $20 \%$ on Campylobacter rectus and Provetella intermedia bacteria.

The next statistical test is LSD which aims to see the difference in effectiveness between the two treatment groups. Based on the results of the LSD posthoc statistical test, it can be seen that all tests obtained $\mathrm{p}$ value $=0.00$, which means that there is a 
Table 1 Average diameter of hydrogel aloe vera antibacterial inhibition $2.5 \%, 5 \%, 10 \%$ and $20 \%$ in campylobacter rectus bacteria

\begin{tabular}{|c|c|c|c|c|c|c|c|}
\hline \multirow{2}{*}{ Group } & \multicolumn{5}{|c|}{ Inhibitor Diameter (mm) } & \multirow{2}{*}{ Mean } & \multirow{2}{*}{ SD } \\
\hline & 1 & 2 & 3 & 4 & 5 & & \\
\hline I & 16.40 & 15.95 & 16.20 & 17.05 & 16.15 & 16.35 & 0.42 \\
\hline II & 12.80 & 12.95 & 13.40 & 13.05 & 12.80 & 13.00 & 0.25 \\
\hline III & 11.40 & 10.95 & 10.80 & 10.95 & 10.75 & 10.97 & 0.26 \\
\hline IV & 8.00 & 8.15 & 8.40 & 7.80 & 8.20 & 8.21 & 0.35 \\
\hline V & - & - & - & - & - & - & - \\
\hline
\end{tabular}

Remarks: (-) there are no obstacles

Group I : Hydrogel Aloe vera 20\%

Group II : Hydrogel Aloe vera $10 \%$

Group III : Hydrogel Aloe vera 5\%

Group IV : Hydrogel Aloe vera $2.5 \%$

Group V : Negative control (hydrogel)

Table 2 Average diameter of hydrogel aloe vera antibacterial inhibition $2.5 \%, 5 \%, 10 \%$ and $20 \%$ in provetella intermedia bacteria

\begin{tabular}{cccccccc}
\hline \multirow{2}{*}{ Group } & \multicolumn{9}{c}{ Inhibitor Diameter $(\mathbf{m m})$} & Mean & SD \\
\cline { 2 - 6 } & $\mathbf{1}$ & $\mathbf{2}$ & $\mathbf{3}$ & $\mathbf{4}$ & $\mathbf{5}$ & & \\
\hline I & 17.20 & 16.80 & 16.40 & 17.40 & 16.55 & 16.87 & 0.42 \\
II & 12.40 & 12.80 & 11.40 & 11.55 & 12.60 & 12.17 & 0.65 \\
III & 10.60 & 10.95 & 10.05 & 10.00 & 10.80 & 10.48 & 0.43 \\
IV & 8.60 & 8.40 & 8.80 & 8.55 & 8.35 & 8.54 & 0.18 \\
V & - & - & - & - & - & - & - \\
\hline
\end{tabular}

Remarks: (-) there are no obstacles

Group I : Hydrogel Aloe vera 20\%

Group II : Hydrogel Aloe vera $10 \%$

Group III : Hydrogel Aloe vera 5\%

Group IV : Hydrogel Aloe vera 2.5\%

Group V : Negative control (hydrogel)

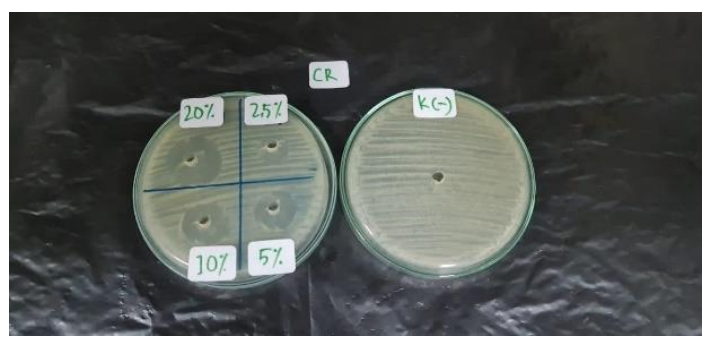

(a)

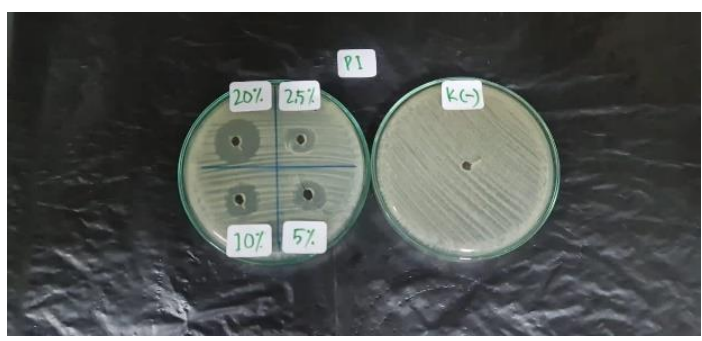

(b)

Figure 1 Inhibition Diameter of the Treatment Group on Disc Discs

(a) Campylobacter rectus, (b) Provetella intermedia 
Table 3 Oneway Anova Test Results

\begin{tabular}{lcccccc}
\hline \multirow{2}{*}{ Group } & \multicolumn{2}{c}{ Campylobacter rectus } & \multicolumn{3}{c}{ Provetella intermedia } \\
\cline { 2 - 7 } & Average & SD & p value & Average & SD & p value \\
\hline Hydrogel Aloe vera $20 \%$ & 16.35 & 0.42 & & 16.87 & 0.42 & \\
Hydrogel Aloe vera 10\% & 13.00 & 0.25 & & 12.17 & 0.65 & 0.00 \\
Hydrogel Aloe vera 5\% & 10.97 & 0.26 & 0.00 & 10.48 & 0.43 & \\
Hydrogel Aloe vera 2.5\% & 8.21 & 0.35 & & 8.54 & 0.18 & \\
\hline
\end{tabular}

Table 4 Posthoc LSD Test Results

\begin{tabular}{lcc}
\hline \multirow{2}{*}{ Group } & Campylobacter rectus & Provetella intermedia \\
\cline { 2 - 3 } & $\boldsymbol{p}$ value & $\boldsymbol{p}$ value \\
\hline I - II & 0.00 & 0.00 \\
I - III & 0.00 & 0.00 \\
I - IV & 0.00 & 0.00 \\
II - III & 0.00 & 0.00 \\
II - IV & 0.00 & 0.00 \\
III - IV & 0.00 & 0.00 \\
\hline
\end{tabular}

\section{Discussion}

This study aims to determine the effectiveness of Aloe vera hydrogel in inhibiting the growth of Campylobacter rectus and Provetella intermedia bacteria. The concentrations of Aloe vera hydrogel tested were $2.5 \%, 5 \%, 10 \%$, and $20 \%$. The hydrogel in this study served as a control group. Each of these materials is dropped into agar media that has been cultured by bacteria. This action was incubated for 1 day and the treatment was replicated 5 times. The antibacterial effectiveness of Aloe vera hydrogel was evaluated by the inhibition zone diameter on agar media and measured by shear calipers.

Based on the research results, it was found that the largest inhibition diameter in inhibiting the growth of Campylobacter rectus bacteria was seen in the $20 \%$ Aloe vera hydrogel group with a mean of $16.35 \pm 0.42$ $\mathrm{mm}$, while the smallest inhibition diameter was $2.5 \%$ of the Aloe vera hydrogel, namely $8.21 \pm 0,35 \mathrm{~mm}$. In Provetella intermedia bacteria, the results also showed that the largest diameter of inhibition was found in $20 \%$ Aloe vera hydrogel and $2.5 \%$ Aloe vera hydrogel. From these results it can be stated that the increasing concentration of Aloe vera hydrogel, the diameter size of the inhibition zone also increases [28].
In this study, it has been proven that the Aloe vera hydrogel has a significant effectiveness in inhibiting the growth of Campylobacter rectus and Provetella intermedia bacteria. The antibacterial effectiveness of Aloe vera hydrogel against Campylobacter rectus and Provetella intermedia was also proven from the oneway ANOVA results $(\mathrm{p}<0.05)$. Susanto \& Girsang's research (2020) shows results that are in line with this study that $5 \%$ and $10 \%$ Aloe vera hydrogel has significant inhibitory power against Fusobacterium nucleatum bacteria with an average inhibitory power in the $5 \%$ Aloe vera hydrogel group $13.00 \pm 0.224 \mathrm{~mm}$ and hydrogel. Aloe vera 10\% was $18.00 \pm 0.261 \mathrm{~mm}$ [28].

The results of the research by Jain et al (2016) also showed that Aloe vera extract gel had antibacterial activity against A.actinomycetemcomitans, C.bacili, S. mutans, and S. aureus. The antibacterial effect of Aloe vera gel is $100 \%$ with an average inhibitory power of 6.9 $\mathrm{mm}$ against $\mathrm{A}$. actinomycetemcomitans, $6.3 \mathrm{~mm}$ against $\mathrm{C}$. bacili, $6.8 \mathrm{~mm}$ against $\mathrm{S}$. mutans and 6.6 $\mathrm{mm}$ against $\mathrm{S}$. aureus [25 ]. Supported by the research results of Adzitey et al (2019) that there is antibacterial effectiveness of Aloe vera extract gel against Escherichia coli and Salmonella enterica bacteria. Aloe vera extract gel can be used prophylactically to reduce 
bacterial infections, especially Escherichia coli and Salmonella enteric bacteria [29].

Campylobacter rectus and Provetella intermedia bacteria are anaerobic gram-negative bacteria that cause periodontal disease. Jain et al (2016) stated that Aloe vera gel is effective in fighting infections, whether it is caused by gram-positive or gram-negative bacteria. The results of this study indicated that Aloe vera hydrogel was more effective against Provetella intermedia bacteria compared to Campylobacter rectus as evidenced by a larger inhibitory diameter [25].

The results of the hydrogel inhibition test of Aloe vera i $2.5 \%, 5 \%, 10 \%$ and $20 \%$ against Campylobacter rectus and Provetella intermedia bacteria showed a clear zone on NA media in the shape of a circle around the disc paper. The clear zone indicates the antibacterial effectiveness of each treatment material. Based on the research of Davis and Stout, the diameter of inhibition formed in the diffusion test measuring $<5$ $\mathrm{mm}$ has weak resistance, $5-10 \mathrm{~mm}$ is moderate, $10-19$ $\mathrm{mm}$ is strong and $20 \mathrm{~mm}$ or more is very strong [28]. From this statement, hydrogel Aloe vera concentrations of $5 \%, 10 \%$, and $20 \%$ have a strong antibacterial effect. This is in line with the research of Susanto \& Girsang (2020) that the $5 \%$ and $10 \%$ Aloe vera hydrogels have a strong antibacterial effect.

The antibacterial effectiveness of the Aloe vera hydrogel against Campylobacter rectus and Provetella intermedia bacteria is probably due to the active compounds in it, especially Aloin and Aloeemodin (antroquinone) which inhibit protein synthesis by bacterial cells [25 These results are also in accordance with the research of Yang et al (2018) that hydrogels with the addition of several antimicrobial agents are more effective against periodontal pathogenic bacteria which are anaerobic and the release of these antimicrobial agents is more controlled [18].

This study has proven that Aloe vera hydrogel has antibacterial effectiveness on Campylobacter rectus and Provetella intermedia. So, this Aloe vera hydrogel can be used as an alternative antibacterial agent to prevent and treat several oral infectious diseases.

\section{Conclusion}

This study resulted in several conclusions, including the mean diameter of hydrogel aloe vera inhibition concentration of $2.5 \%, 5 \%, 10 \%$ and $20 \%$ in Campylobacter rectus bacteria was $16.06 \pm 0.19 \mathrm{~mm}$, $8.21 \pm 0.35 \mathrm{~mm}, 10.97 \pm 0.26 \mathrm{~mm}, 13.00 \pm 0.25 \mathrm{~mm}$, and $16.35 \pm 0.42 \mathrm{~mm}$. The mean diameter of hydrogel aloe vera inhibition concentration of $2.5 \%, 5 \%, 10 \%$ and $20 \%$ in Provetella intermedia bacteria was $8.54 \pm$ $0.18 \mathrm{~mm}, 10.48 \pm 0.43 \mathrm{~mm}, 12.17 \pm 0.65 \mathrm{~mm}$, and $16.87 \pm 0.42 \mathrm{~mm}$. There is an antibacterial effectiveness of hydrogel Aloe vera concentrations of 2.5\%, 5\%, 10\% and $20 \%$ on Campylobacter rectus and Provetella intermedia bacteria.

\section{References}

1. Dumitrescu, AL. 2015. Editorial: Periodontal disease - a public health problem. Frontiers 2014; 3(278).

2. Notohartojo IT, Surartri MAL, Setiawaty V. The association between hypertension, physical activity, and brushing technique with periodontal disease. Bali Medical Journal (Bali Med J) 2019; 8(1): 216-20.

3. Nazir M, Al-Ansari A, Al-Khalifa K, Alhareky M, et al. Global prevalence of periodontal disease and lack of its surveillance. Scientific World Journal 2020; 20: 1-8.

4. Tonetti MS, Bottenberg P, Conrads G, et al. Dental caries and periodontal diseases in the ageing population: call to action to protect and enhance oral health and well-being as an essential component of healthy ageingconsensus report of group 4 of the joint EFP/ORCA workshop on the boundaries be. Journal of Clinical Periodontology 2017; 44(18): 135-44.

5. Susanto A, Rusjanti J, Rusminah N, Hendiani I, Komara I, Metta P. The prevalence of chronic periodontitis in the City of Bandung, Indonesia: a cross sectional study. International Journal of Medical Science and Clinical Invention 2018; 5(07): 3914-16.

6. Abdelmonem HM, Khashaba OH, Al-Daker MA, 
Moustafa MD. Effects of aloe vera Gel as an adjunctive therapy in the treatment of chronic periodontitis: a clinical and microbiological study. Mansoura Journal of Dentistry 2014; 1(3): 11-9.

7. Zhao H, Hu, J, Zhao, L. Adjunctive subgingival application of Chlorhexidine gel in nonsurgical periodontal treatment for chronic periodontitis: a systematic review and meta-analysis. BMC Oral Health 2020; 20(34): 1-12.

8. Reynolds I, Duane B. Periodontal disease has an impact on patients quality of life. EvidenceBased Dentistry 2018; 19(1): 14-5.

9. Tonetti MS, Jepsen S, Jin L, Otomo-Corgel L. Impact of the global burden of periodontal diseases on health, nutrition and wellbeing of mankind: a call for global action. Journal of Clinical Periodontology 2017; 44(5): 456-62.

10. Singh HP. Muzammil, Satish G, Babu KN, Vinod KS; et al. Comparative study to evaluate the effectiveness of aloe vera and metronidazole in adjunct to scaling and root planing in periodontitis patients. Journal of International Oral Health 2016; 8(3): 374-77.

11. How KY, Song KP, Chan KG. Porphyromonas gingivalis: an overview of periodontopathic pathogen below the gum line. Front Microbiol 2016; 7: 1-14

12. Alwaeli AZJ. Anaerobic bacteria associated periodontitis. In book: Oral Microbiology in Periodontitis. 2018. DOI: $\underline{10.5772 / \text { intechopen.76352 }}$

13. Chukkapalli SS, Rivera-Kweh MF, Velsko IM, Chen H, Zheng D, Bhattacharrya I, et al. Chronic oral infection with major periodontal bacteria Tannerella forsythia modulates systemic atherosclerosis risk factors and inflammatory markers. FEMS Pathogens and Disease 2015; 73(3): 1-12.

14. Kononen E, Kumar PS. Bacteriologi of Periodontal disease. Molecular Medical Microbiology 2015; 2: 9657-68.

15. Baggot D, Giguere S. Principal of antimicrobial drug bioavailability and disposition. In :
Antimicrobial Therapy in Veterinary Medicine. Fifth ed. Lowa: John Wiley \& Sons. 2013.

16. Gulrez, S, Philips GO, Al-Assaf S. Hydrogels : Methods of preparation, characterization, and applications. Progress in Molecular and Environmental Bioengineering From Analysis and Modeling to Technology Applications 2011; 117-50.

17. Yuliani SH, Fudholi A, Pramono S, Marchaban. Physical properties of wound healing gel of ethanolic extract of binahong (anredera cordifolia (ten) steenis) during storage. Indonesian j. Pharm 2012; 23(4) : 203 - 8.

18. Yang K, Han Q, Chen B, Zheng Y, Zhang K, et al. Antimicrobial hydrogels: promising materials for medical application. IJN 2018; 1(3): 2217-63.

19. Li S, Dong $\mathrm{S}, \mathrm{Xu} \mathrm{W}$, et al. Antibacterila hydrogels. Adv. Sci 2018; 5(5): 1700527.

20. Lecic J, Cakic S, Pavlovic JO, Cicmil A, Vukotic O, Petrovic V, et al. Different methods for subgingival application of chlorhexidine in the treatment of patients with chronic periodontitis. Acta Odontol Scand 2016; 74: 502-7.

21. Binshabaib M, Aabed K, Alotaibi F, Alwaqid M, Alfraidy A, Alharthi S. Antimicrobial efficacy of 0.8\% Hyaluronic Acid and 0.2\% Chlorhexidine against Porphyromonas gingivalis strains: An in-vitro study. Pak J Med Sci 2020; 36(2): 11114.

22. Bowen J, Cole C, McGlennen R. Comparison of antimicrobial and wound healing agents on oral fibroblast viability and in-vivo bacterial Load. Dentistry 2015; 5(6): 1-6.

23. Hasriati E, Anggani HS, Purbiati M, Bachtiar EW. Antibacterial effect of $2 \%$ chlorhexidine and $1 \%$ chitosan mouthwash on bacteria during orthodontic miniscrew use. International Journal of Applied Pharmaceutics 202; 12(2): 8-12.

24. Shah R, Gayatri GV, Mehta DS. Application of herbal products in management of periodontal diseases: A mini review. International Journal 
of Oral Health Sciences 2020; 5(1): 38-44.

25. Jain S, Rathod N, Nagi R, et al. Antibacterial effect of aloe vera gel against oral pathogens: an in-vitro study. Journal of Clinical and Diagnostic Research 2016; 10(11): ZC41-ZC44.

26. Gharibi D, Khosravi M, Hosseini $Z$, et al. Antibacterial effects of aloe vera extracts on some human and animal bacterial pathogens. J Med Microbiol Infec Dis 2015; 3(1-2): 6-10.

27. IARC. Some drugs and herbal product : monographs. 2016; 108: 37-71. Diakses dari
https://monographs.iarc.fr/ENG/Monograph s/vol 108/mono108-01.pdf

28. Susanto C, Girsang E. The effectiveness of aloe vera hydrogel against fusobacterium nucleatum. IJPST 2020; 7(3): 118-25.

29. Adzitey F, Agholosu AA, Udoka UJ. Antibacterial effect of aloe vera gel extract on escherichia coli and salmonella enterica isolated from the gastrointestinal tract of guinea fowls. World Vet J 2019; 9(3): 166-173. 